\title{
Habitat use and selection patterns inform habitat conservation priorities of an endangered large carnivore in southern Europe
}

\author{
Miguel de Gabriel Hernando ${ }^{1,2, \#}$, Alexandros A. Karamanlidis ${ }^{1,3, \#, *}$, \\ Konstantinos Grivas ${ }^{1}$, Lambros Krambokoukis ${ }^{1}$, Georgios Papakostas ${ }^{1}$, John \\ Beecham $^{1,4}$
}

\begin{abstract}
${ }^{1}$ ARCTUROS, Civil Society for the Protection and Management of Wildlife and the Natural Environment, Florina 53075, Greece ${ }^{2}$ Department of Biodiversity and Environmental Management, Faculty of Biological and Environmental Sciences, Universidad de León, León 24007, Spain
\end{abstract}

${ }^{3}$ Faculty of Environmental Sciences and Natural Resource Management, Norwegian University of Life Sciences, Ås 1432, Norway ${ }^{4} 7252$ N. Pierce Park Lane, Boise, ID 83703, USA

\begin{abstract}
Understanding the habitat use and selection patterns of endangered species is essential in developing management measures that will protect critical habitat and mitigate human-wildlife conflicts. This understanding is particularly important in areas with high anthropogenic pressures. To understand the ecological role of various habitat types in the conservation of an endangered large carnivore in southern Europe, with its distinct environmental conditions and predominantly anthropogenic landscapes, we studied 18 GPS-collared brown bears Ursus arctos in Greece. We examined the use and selection of habitats according to age and sex categories and behavioral status during 5 ecologically defined seasons. Areas with rough terrain were identified as important refuge areas and were used by all bears in late hyperphagia and emergence. All bears used areas closer to human-related habitat features during the night. Habitat selection was positive for areas with rough terrain and naturalized (i.e. abandoned or not intensive) crops and areas close to water courses, while high-altitude areas and roads were avoided. The selection or avoidance of other habitats varied across bear categories and between stationary and moving behavior. We recommend that the results of the study be used to develop guidelines for species conservation and allow for prioritizing management actions that will promote the conservation of bears in Greece. In particular, the habitat use patterns provide information on how to limit interactions between humans and bears in space and/or time, while the habitat selection patterns indicate suitable habitats that should be protected/improved based on their importance and ecological role for the species.
\end{abstract}

KEY WORDS: Brown bear · Ursus arctos $\cdot$ Greece $\cdot$ Habitat selection $\cdot$ Habitat use $\cdot$ Species recovery

\section{INTRODUCTION}

The thorough understanding of animal habitat use and selection patterns is essential in developing effective management measures to protect critical habitats, safeguard the necessary resources for a

*Corresponding author: akaramanlidis@gmail.com

\#These authors contributed equally to this work species' persistence, mitigate its potential negative interactions with humans and ultimately contribute to the conservation of endangered species (Morrison et al. 2006). This is particularly important for large carnivores, especially in anthropogenic areas, where habitat alteration may force animals to utilize subop- 
timal habitat types (Martínez-Abraín \& Jiménez 2016). The study of how animals use habitats through time and across space (i.e. habitat use) and the types of habitats that are likely to be used in relation to their availability (i.e. habitat selection; Garshelis 2000), provides information on critical habitats that can be used to prioritize conservation efforts (Schofield et al. 2007) in the European context of anthropogenic landscapes (Linnell et al. 2008).

Habitat use and selection processes are inextricably linked to the characteristics of animal movement (Martin et al. 2009), behavior (Moe et al. 2007) and the way that an animal perceives the habitat or evaluates the availability of resources (Manning et al. 2004). Therefore, dynamic approaches to define habitat sampling units (i.e. resource units; RUs), such as dynamic Brownian bridge movement models (dBBMMs) (Kranstauber et al. 2012) are currently among the state-of-the-art methods to evaluate the factors influencing wildlife habitat ecology (Byrne et al. 2014, Hinton et al. 2015, 2016). According to this approach, resource units can be defined as the areas where animals are or could be present during a certain time frame based on their movement patterns; the intensity of use of these RUs, also known as the utilization distribution (UD; Worton 1989), reflects how animals select for or against a certain habitat feature when encountering it (Dugatkin \& Reeve 2000).

Brown bears Ursus arctos are globally considered by the IUCN as species of Least Concern. They are the only ursid in Europe, where several populations, especially those inhabiting the southern parts of the continent, are small, isolated and threatened by habitat loss and fragmentation and by human-bear conflicts (Penteriani et al. 2020, Swenson et al. 2020). Brown bears in Greece present an interesting case for highlighting how the deeper understanding of the habitat ecology of a large carnivore can help inform conservation priorities of an endangered species. In Greece, numbering fewer than 500 individuals (Karamanlidis et al. 2015), and considered to be endangered (Mertzanis et al. 2009), brown bears reach their southernmost European distribution. Their range in Greece has been expanding in recent years (Bonnet Lebrun et al. 2020), and their population has been recovering, both demographically (Karamanlidis et al. 2015) and genetically (Karamanlidis et al. 2018). This has been partly facilitated by specific behavioral adaptations in the overall movement patterns of the species (de Gabriel Hernando et al. 2020) combined with the rewilding of the countryside after the rural abandonment by humans (Mertzanis et al. 2020).
Brown bear habitat use and selection in Europe has been systematically studied, mainly in the northern parts of the continent (Swenson et al. 2020). Throughout northern and central Europe, human activity (Martin et al. 2010) and environmental characteristics (e.g. terrain roughness) have been shown to have varying effects on habitat use and selection, depending on bear age and sex (Nellemann et al. 2007), time of day (Moe et al. 2007), season (Pop et al. 2018) and behavioral status (i.e. stationary vs. moving behaviors; Moe et al. 2007). In contrast, our understanding of the habitat ecology of brown bears in southern Europe (i.e. Mediterranean region), with its distinct environmental conditions and high anthropogenic pressures, is still incomplete (but see e.g. Mertzanis et al. 2008, Piédallu et al. 2019). In addition, rear-edge populations (i.e. animal populations residing at the lowlatitude distribution limits), such as the brown bear population in Greece, are of paramount importance for the conservation of a species (Hampe \& Petit 2005).

To understand the habitat ecology of brown bears in Greece, we examined the circannual and circadian habitat use and habitat selection patterns of individual GPS-collared brown bears across space and time. Our main objective was to gain insights into the ecological role of various habitat types for the species, thus providing temporal and spatial information that can be used to identify conservation priorities for an endangered brown bear population living in an anthropogenic landscape.

\section{MATERIALS AND METHODS}

\subsection{Study area and animals}

The study was carried out in the western part of the brown bear range in Greece, an area that extends approximately over the $250 \mathrm{~km}$ long Greek part of the Pindos mountain range $\left(40^{\circ} 00^{\prime} \mathrm{N}, 21^{\circ} 03^{\prime} \mathrm{E}\right)$ (Fig. 1). The study area forms a mosaic of elevations and typical Mediterranean habitats and is characterized by long, arid summers and short, but cold and rainy winters. Approximately $19 \%$ of the study area is covered by mature broadleaf forest, dominated by oak (Quercus sp.) and beech (Fagus sp.), 7\% is mature pine (Pinus sp.) and fir (Abies sp.) coniferous forest, and $5 \%$ is mixed forest. Transitional woodland and shrublands with junipers (Juniperus sp.), European box Buxus sempervirens and other sclerophyllous species occupy approximately 20\%, natural grasslands and pastures occupy approximately $15 \%$, and rocky outcrops and bare grounds approximately 


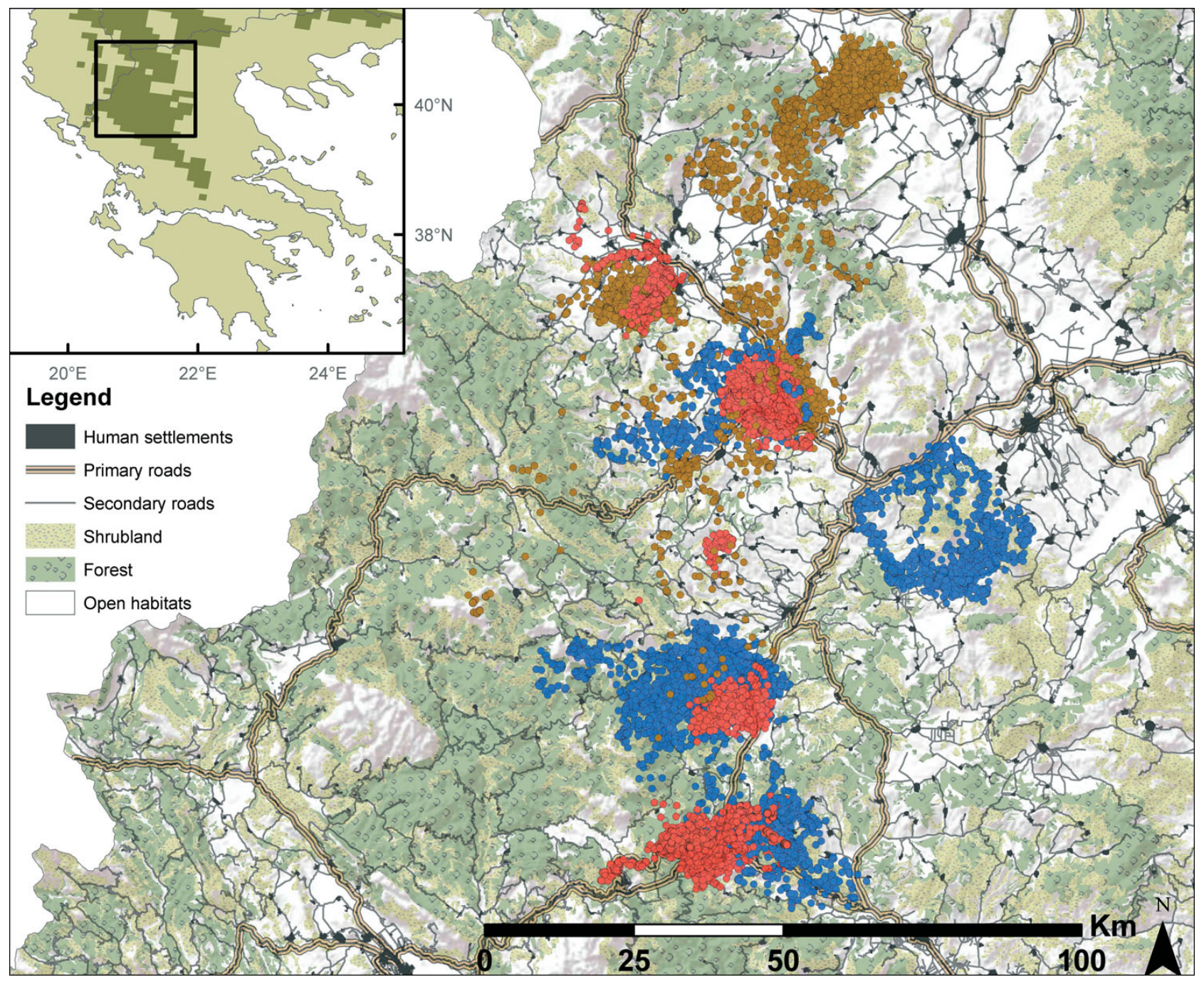

Fig. 1. Main habitat characteristics of the study area, indicating the GPS locations of collared adult female (red dots), adult male (blue dots) and subadult (brown dots) bears used in this study. The inset presents the approximate brown bear distribution in Greece, according to Chapron et al. (2014)

$2 \%$ of the habitat. Human-occupied landscapes account for $32 \%$ of the habitat. Near rural areas, natural habitats are disrupted by naturalized crops $(12 \%)$, which are mosaics of agricultural patches where low-intensity or abandoned crops mixed with fruit trees, shrubs and open woodlands. The main floodplains and the surroundings of human settlements are covered by intensive wheat and corn crops $(20 \%)$. Elevations range from $194 \mathrm{~m}$ above sea level (a.s.l.) up to the peak of Mount Smolikas at $2637 \mathrm{~m}$ a.s.l. Compared to other bear ranges in Europe, the intensity of human activity in the study area, as measured by population density, is, on average, relatively high (i.e. 79 people $\mathrm{km}^{-2}$ ).

We used Aldrich leg-hold snares (Johnson \& Pelton 1980) to catch bears and monitored the traps using very high frequency alarms that were checked every $2 \mathrm{~h}$ and visually checked every morning. Bears were tranquilized with an initial intramuscular injection $(3 \mathrm{ml})$ of a mixture of tiletamine and zolazepam (Zoletil 50; Virbac) using a $\mathrm{CO}_{2}$ injection rifle (Model I.M.; DANiNJECT) and a second injection by hand of $2 \mathrm{ml}$ Zoletil 50 .

We considered bears $2-3$ yr of age to be subadults and older bears to be adults and assigned all individuals to 3 categories (i.e. adult females, adult males and subadult males). We fitted 3-D GPS collars (Simplex, Televilt; GPS Plus, Vectronic Aerospace) to 6 adult females, 6 adult males and 5 subadult males (2003-2013) using multilayered cotton spacers destined to break and release the collar in 1-2 yr. In addition, we collared 1 subadult female that accompanied her mother, who was not collared during the 
entire study period; this was the only female-dependent cub pair in the study. Although habitat use and selection of females with dependent cubs might differ from those of lone females due to their smaller home ranges (Dahle \& Swenson 2003), we included this female-cub pair within the adult female category because their movement patterns were more similar to this group than to adult or subadult males (de Gabriel Hernando et al. 2020). The GPS fix rate varied from 1 to $3 \mathrm{~h}\left(8-24\right.$ fixes $\left.\mathrm{d}^{-1}\right)$. Seven bears (4 adult females, 2 adult males and 1 subadult male) were also fitted with a dual-axis motion sensor (Ziółkowska et al. 2016). We collected a total of 37499 GPS fixes over 3072 tracking days for 7 adult females, 6 adult males, and 5 subadult males (for details see Table S1 in the Supplement at www.intres.com/articles/suppl/n044p203_supp.pdf.

\subsection{Data treatment}

To define the resource units for the habitat use and selection analyses, we fitted a dBBMM to the complete movement path of each animal by calculating the $50 \%$ UD contours and the Brownian motion variance $\sigma_{\mathrm{m}}^{2}$ for all the individual time steps within each movement path (packages 'move' [Kranstauber et al. 2019] and 'moveud' [Collier 2013] in the R statistical computing environment [R Core Team 2013]; see Text $\mathrm{S} 1$ for further details). Following the procedure described by Byrne et al. (2014), we then indexed each UD contour with the time of the first location belonging to that individual time step. Time steps were classified according to behavioral status as stationary (i.e. sleeping, resting, feeding, etc.) or moving (i.e. walking, running or foraging), based on their Brownian motion variance (de Gabriel Hernando et al. 2020). Finally, we selected 12 habitat variables (Table 1) that were converted to raster maps and intersected with the UD time step contours to calculate average values.

Distance-based habitat variables (Table 1) were calculated by creating path distance raster layers using a digital elevation model at $30 \mathrm{~m}$ resolution (USGS 2006) as a vertical factor. Path distance to polygon features was calculated from the feature edge towards the exterior (i.e. negative proximity values) and the interior (i.e. positive proximity values) of the polygon. Path distances to polyline layers (i.e. roads and water courses) were converted to negative proximity values. Roughness was calculated as the difference in elevation between neighboring

Table 1. Details of the habitat variables used in the present study

\begin{tabular}{|c|c|c|}
\hline Variable & Description & Source \\
\hline Altitude & $\begin{array}{l}\text { Elevation above sea level calculated from digital } \\
\text { elevation model at } 30 \mathrm{~m} \text { resolution }\end{array}$ & \multirow[t]{2}{*}{$\begin{array}{l}\text { Shuttle Radar Topography Mission (SRTM) } \\
\text { digital elevation model (USGS 2006) }\end{array}$} \\
\hline Roughness & $\begin{array}{l}\text { Terrain roughness index (i.e. difference in eleva- } \\
\text { tion between neighboring cells; Riley et al. 1999), } \\
\text { calculated from a digital elevation model at } 30 \mathrm{~m} \\
\text { resolution }\end{array}$ & \\
\hline Forest (proximity) & $\begin{array}{l}\text { Path distance to forested areas, including broad- } \\
\text { leaved, coniferous or mix forests }\end{array}$ & \multirow{5}{*}{$\begin{array}{l}\text { Modified from Corine Land Cover } 2006 \\
\text { (CLC) seamless vector data, Version } 16 \\
\text { (European Commission, 04/2012) (https:// } \\
\text { land.copernicus.eu/pan-european/corine- } \\
\text { land-cover/clc-2006) }\end{array}$} \\
\hline Shrubland (proximity) & $\begin{array}{l}\text { Path distance to transitional shrubland } \\
\text { or sclerophyllous vegetation }\end{array}$ & \\
\hline Grassland (proximity) & Path distance to grassland and pasture & \\
\hline $\begin{array}{l}\text { Naturalized crops } \\
\text { (proximity) }\end{array}$ & $\begin{array}{l}\text { Path distance to naturalized crops or low- } \\
\text { intensity agricultural patches }\end{array}$ & \\
\hline $\begin{array}{l}\text { Intensive crops } \\
\text { (proximity) }\end{array}$ & Path distance to intensive crops & \\
\hline $\begin{array}{l}\text { Water courses } \\
\text { (proximity) }\end{array}$ & $\begin{array}{l}\text { Path distance to permanent water courses } \\
\text { (excluding lakes) }\end{array}$ & \multirow{5}{*}{$\begin{array}{l}\text { Modified from OpenStreetMap Data in } \\
\text { layered GIS format (www.openstreetmap. } \\
\text { org/\#map=6/38.359/23.810) }\end{array}$} \\
\hline $\begin{array}{l}\text { Human settlements } \\
\text { (proximity) }\end{array}$ & $\begin{array}{l}\text { Path distance to human settlements } \\
\text { (villages and towns) }\end{array}$ & \\
\hline $\begin{array}{l}\text { Primary roads } \\
\text { (proximity) }\end{array}$ & $\begin{array}{l}\text { Path distance to motorways or primary roads often } \\
\text { linking larger towns }\end{array}$ & \\
\hline $\begin{array}{l}\text { Secondary roads } \\
\text { (proximity) }\end{array}$ & $\begin{array}{l}\text { Path distance to secondary or tertiary road often } \\
\text { linking smaller towns and villages }\end{array}$ & \\
\hline $\begin{array}{l}\text { Unpaved roads } \\
\text { (proximity) }\end{array}$ & Path distance to minor roads, generally unpaved & \\
\hline
\end{tabular}


cells (Riley et al. 1999). All variable calculations were performed with the Spatial Analyst toolbox in ArcGIS 10 (Environmental Systems Research Institute). The absolute Pearson correlation coefficient for any pair of variables was less than 0.50 , with the exception of the pairs 'altitude-proximity to intensive crops' $(\mathrm{R}=-0.58)$ and 'proximity to settlements-proximity to secondary roads' $(\mathrm{R}=0.67)$. The variance inflation factor was below 4.0 for all variables, suggesting low collinearity effects (Heiberger \& Holland 2004).

To analyze habitat use and selection across seasons, we used the ecologically defined seasons for bears in Greece identified by de Gabriel Hernando et al. (2020), i.e. 'emergence' (EM; 1 March-21 April), 'mating' (MA; 22 April-21 June), 'post-mating' (PM; 22 June-7 August), 'early hyperphagia' (eHY; 8 August-7 October) and 'late hyperphagia' (lHY; 8 October-15 December). We did not include data from the denning period (16 December-28 February) in our analyses due to a small sample size of successful GPS fixes.

\subsection{Data analysis}

To study the circannual and circadian habitat use patterns of brown bears in Greece, we considered the $50 \%$ dBBMM time step UD contours of each individual as the used resource units. For each bear category and each of the 12 habitat variables (i.e. response variables), we fitted a generalized additive mixed model (GAMM) to test the effects of the predictor variables (i.e. day of the year for circannual and hour of the day for circadian) while applying a cyclic cubic spline smoother to them. For the circannual analyses, we included the individual bear ID-year (i.e. bears monitored for more than 1 yr were considered different sample units to account for annual variations within individuals) as a random effect, while for the circadian analyses, we included season as a random effect.

To study habitat selection, we followed the Design III approach, i.e. the animals were identified and both the use and the availability of habitat were measured (Manly et al. 2002). Available RUs for each bear were obtained by calculating the $50 \%$ dBBMM time step UD contours of the alternative random trajectories that were created within the annual $100 \%$ minimum convex polygon of each individual ( $\mathrm{R}$ package 'adehabitatLT', Calenge 2006). We started the random trajectories at the capture location (Calenge et al. 2009) or at the first location during emergence if a bear was monitored for more than $1 \mathrm{yr}$. We then followed the same pattern of distances and times between successive locations as the actual bear trajectories according to the season, but randomized the turning angles. For each bear category and behavioral status, we fitted a separate generalized linear mixed model (GLMM) with a binary response $(0=$ available RUs; $1=$ used RUs) and a logistic link using 250 randomly selected and stratified by season used and available RU records for each bear. We tested all additive combinations of the 12 habitat variables ( $\mathrm{R}$ package 'MuMIn', Bartón 2019) including the bear ID and season as crossed random effects. For each bear category and behavioral status, we selected the model with the lowest value of Akaike's information criterion corrected for small sample sizes $\left(\mathrm{AIC}_{\mathrm{c}}\right)$ and all of its significant variables $(\mathrm{p} \leq 0.05)$ as the best-fitting model supporting habitat selection while considering the standardized coefficient estimates as indicators of habitat selection (i.e. positive estimates) or avoidance (i.e. negative estimates). The relative order of importance for each variable was calculated based on the $\Delta \mathrm{AIC}_{\mathrm{c}}$ between the full model and each model for which the target variable was removed.

\section{RESULTS}

\subsection{Circannual and circadian habitat use}

Circannual habitat use patterns differed across brown bear categories, with the exception of areas with a rougher terrain that were used by all bears in lHY and EM (Fig. 2). Compared to males, females generally showed more homogeneous habitat use patterns throughout the year and used areas closer to human settlements in eHY and $\mathrm{lHY}$; adult males showed the highest seasonal variation in their proximity to most habitat features (Fig. 2). Adult males used shrublands and the most natural areas, such as higher-elevation areas and areas closer to grasslands from eHY to EM and areas closer to water courses in PM. From MA to eHY, adult and subadult males used areas closer to anthropogenic habitat features, such as human settlements and naturalized and intensive crops (Fig. 2).

In general, all bear categories used areas closer to natural habitat features (e.g. forests, shrublands, areas with high altitude and rough terrain) during the day and areas closer to human-related habitat features (e.g. intensive and naturalized crops, human 

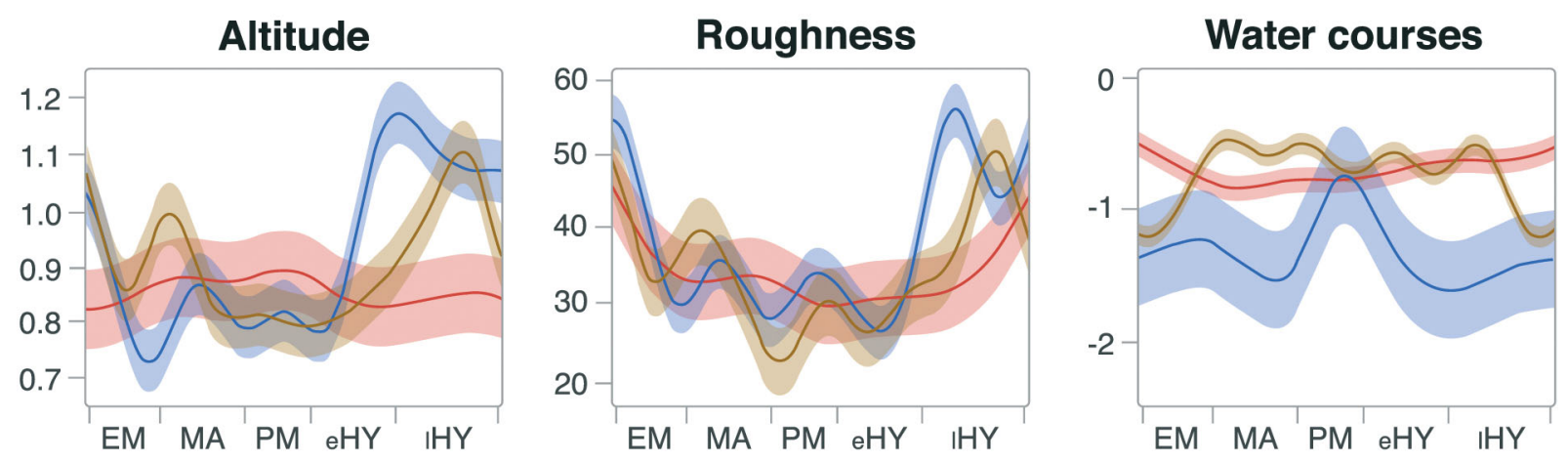

Forest

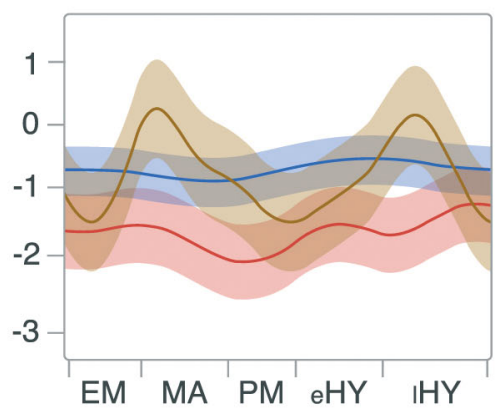

Shrubland

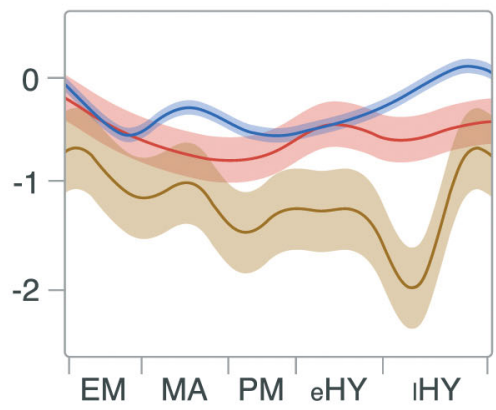

Grassland

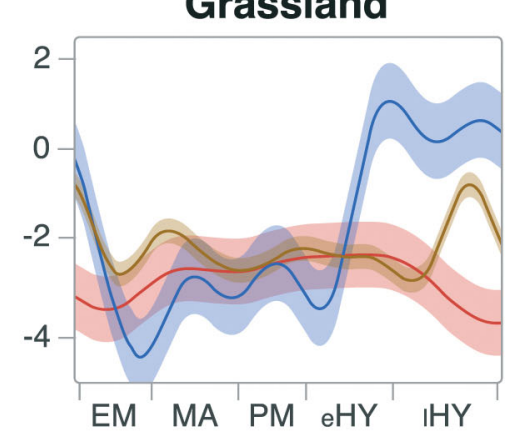

\section{Naturalized crops}
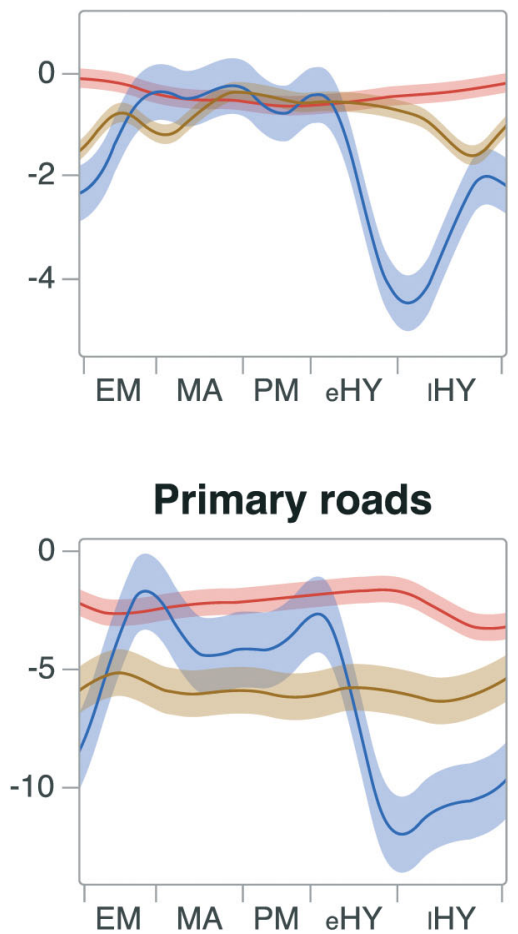

Intensive crops

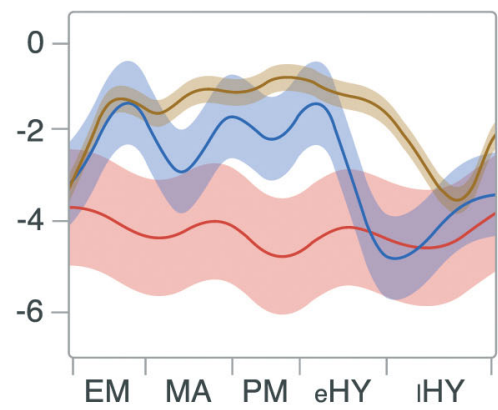

Secondary roads

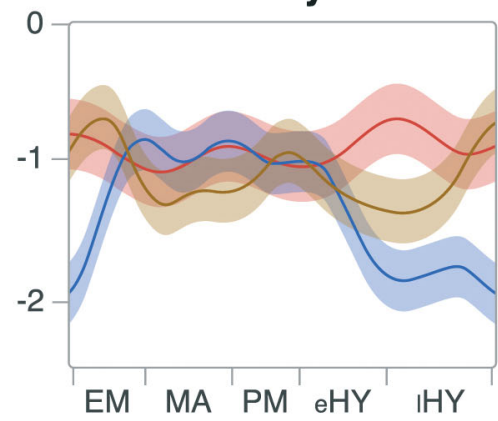

\section{Settlements}

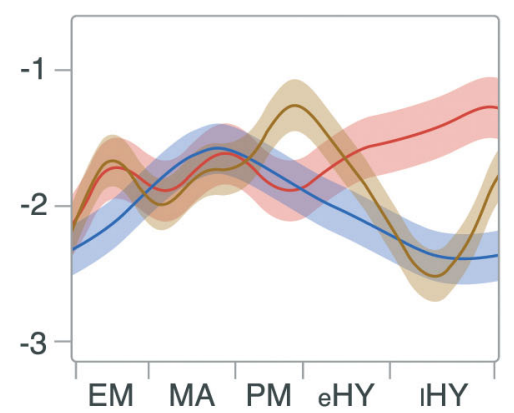

Fig. 2. Habitat use according to altitude (km a.s.l), terrain roughness (m) and proximity to habitat features (km), as predicted by GAMMs ( $y$-axis) for adult female (red line), adult male (blue line) and subadult (brown line) brown bears in Greece across the biological seasons ( $x$-axis) (EM: emergence; MA: mating; PM: post-mating; eHY: early hyperphagia; lHY: late hyperphagia). Shaded areas indicate the standard deviation for each bear category. The smooth terms for all models are significant 

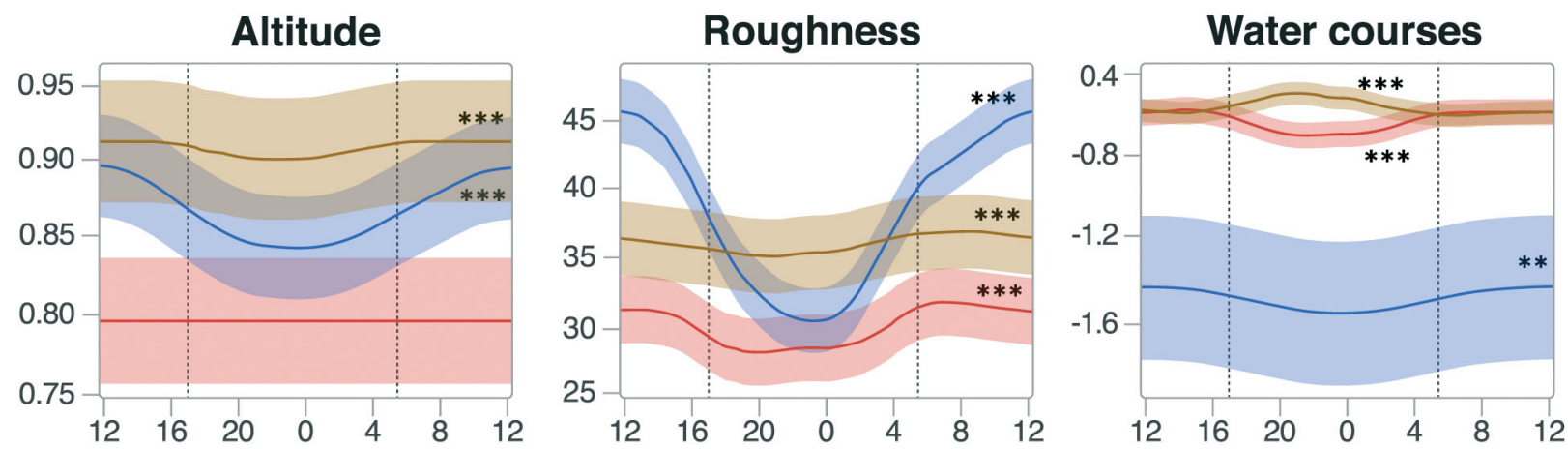

Forest

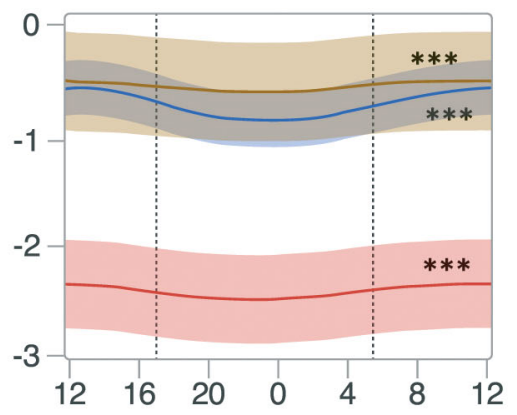

Naturalized crops

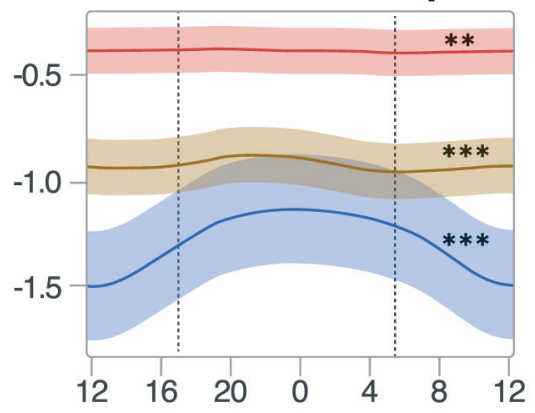

Primary roads

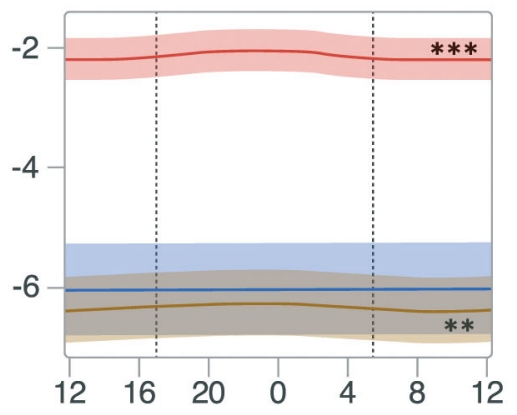

Shrubland

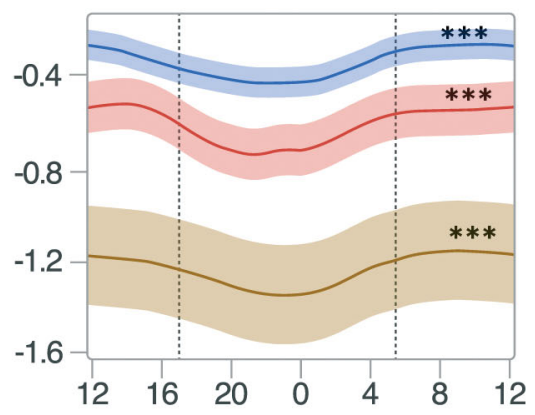

Intensive crops
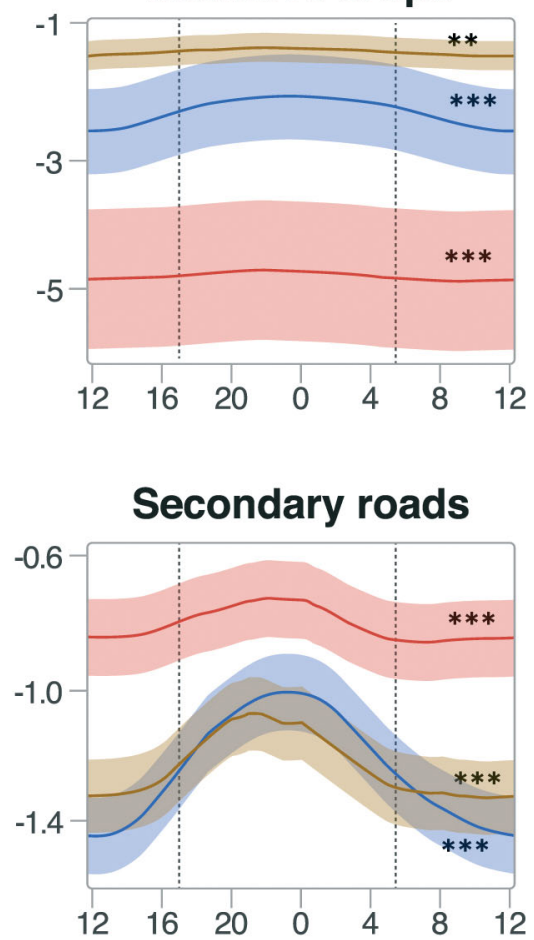

Grassland

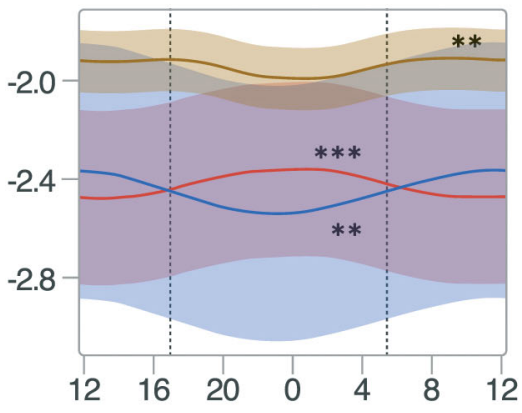

\section{Settlements}
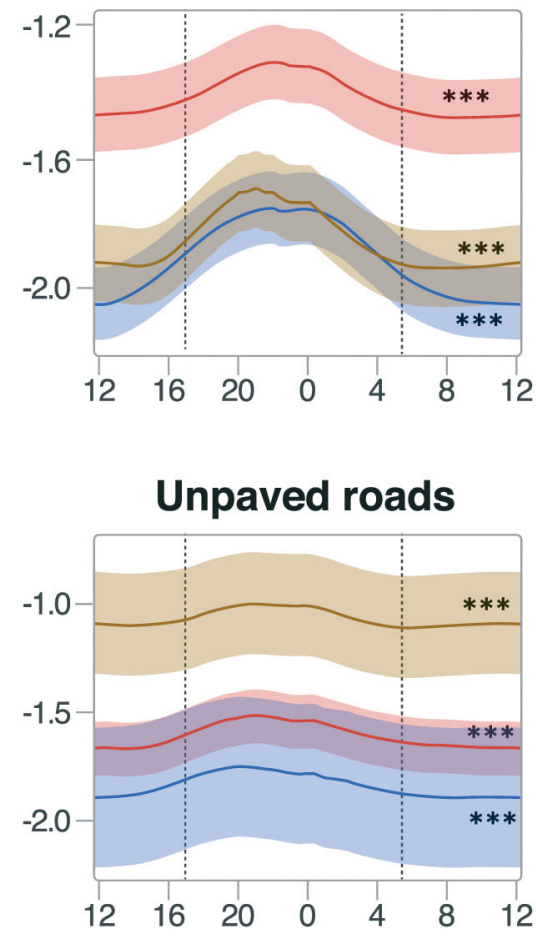

Fig. 3. Habitat use according to altitude (km a.s.l), terrain roughness (m), and proximity to habitat features (km), as predicted by GAMMs ( $y$-axis) for adult female (red line), adult male (blue line) and subadult male (brown line) brown bears in Greece across hours of the day ( $x$-axis). Shaded areas indicate the standard deviation for each age-sex class. Dotted vertical lines indicate the average sunset and sunrise from the emergence season through to the late hyperphagia season. The significance levels of the smooth terms are ${ }^{* * *} p<0.001 ;{ }^{* *} p<0.01$; and ${ }^{*} p<0.05$ 
settlements, primary, secondary and unpaved roads) during the night (Fig. 3). Water courses were approached during the day by adult females and males and during the night by subadult males; areas close to grasslands were used during the day by subadult and adult males and during the night by females. Overall, adult males had a more pronounced daynight shift in their proximity to most of the habitat features (Fig. 3).

\subsection{Habitat selection for stationary and moving behaviors}

In general, bears showed a positive selection for areas with rough terrain and naturalized crops and areas close to water courses while avoiding high-altitude areas and primary and unpaved roads (Fig. 4). However, habitat selection showed distinct differences across bear categories and behavioral statuses; adult males selected for forests, shrublands and grasslands, which were avoided or not selected by females and subadult males. Adult males also selected for areas close to human settlements, which were avoided by adult females. Intensive crops were selected by adult females and subadult males for moving behaviors and were avoided by adult and subadult males for stationary behaviors. Secondary roads were selected by adult females for moving behaviors, but avoided by males for all behaviors (Fig. 4; see Tables S2 \& S3 for details on model selection and GLMM estimates).

\section{DISCUSSION}

Understanding habitat use and selection patterns is of paramount importance in wildlife conservation, as behavioral responses may often be the first measurable reactions that animals show in response to (human-induced) environmental changes and can help determine the capacity of a species to adapt to these changes (Sih et al. 2011). In contrast to most studies that have been carried out in the northern and central parts of Europe, our study provides new contributions to understanding the habitat ecology of brown bears by examining them in the anthropogenic landscape of southern Europe.

Overall, the results of the study indicate that habitat use and selection by bears in Greece favored habitats with low anthropogenic disturbance that are suitable for covering the biological requirements of the species (i.e. including nutrition, refuge, hiberna- tion and reproduction) (Naves et al. 2003, Posillico et al. 2004).

All bears in this study used areas with high topographic complexity (i.e. areas with rough terrain) in IHY and EM. The use of such areas at this time of the year is a behavior that has been recorded throughout the range of the species (e.g. Europe: Swenson et al. 2020; North America: Apps et al. 2004) and has been associated with better protection from humans, better sheltering and denning opportunities (Linnell et al. 2000, Nielsen et al. 2004) and the existence of complementary feeding habitats (May et al. 2008, Güthlin et al. 2011). The increased variability in circannual habitat use by males was likely a result of their higher mobility (de Gabriel Hernando et al. 2020) that enabled them to adapt more dynamically to the spatio-temporal changes in resource and refuge availability of the fragmented landscape in Greece. Furthermore, males used areas closer to anthropogenic habitat features from MA to eHY than during the rest of the year, likely in an attempt to make use of the primary food sources that are available at this time of the year: the diet of bears in Greece in the summer includes a relatively high proportion of cereals and soft mast (Paralikidis et al. 2010), which are found mainly in anthropogenic landscapes. This behavior is in accordance with previous information (Mertzanis et al. 2008) and is consistent with the patterns of human-bear conflicts (i.e. damage to crops) in the country (Karamanlidis et al. 2011).

Brown bear habitat use in Greece had a clear circadian pattern, i.e. closer to natural habitats during the day and closer to human habitats during the night. This pattern was similar across all bear categories, with the exception of proximity to grasslands and water courses. Circadian habitat use patterns of brown bears have been recorded previously in North America (Nielsen et al. 2004) and in Scandinavia, where human activity did not appear to have relevant effects (Ordiz et al. 2014), probably because human densities in Scandinavia are among the lowest within bear ranges in Europe (Ordiz et al. 2011). In contrast, studies in areas with higher human density, such as Greece (Mertzanis et al. 2008) or Spain (Naves et al. 2001), have indicated that human activity may have a significant effect on circadian habitat use. Consequently, the use of natural habitats by females and subadult males during the day should be regarded as a compromise between avoiding human activity and intraspecific aggression or competition with adult males while satisfying higher nutritional needs and lack of experience, respectively (Elfström 

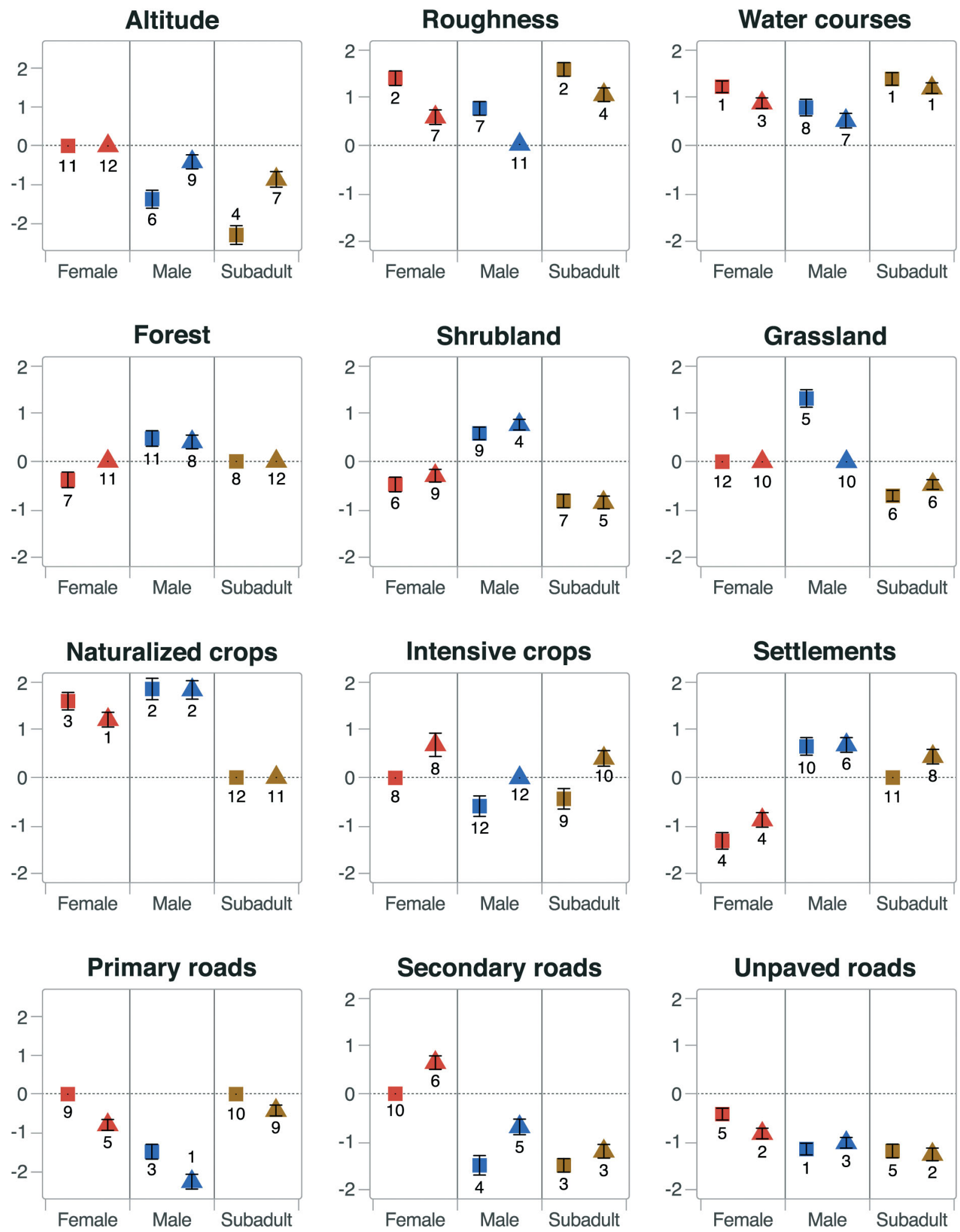

Fig. 4. Standardized coefficients $(\beta)$ and standard errors obtained in the best-fitting GLMM supporting habitat selection for stationary behaviors (squares) and moving behaviors (triangles) for adult female (red), adult male (blue) and subadult male (brown) brown bears in Greece. Symbols at the $y$-axis value of 0 represent variables that did not enter the best-fitting models for each behavior and bear category. Variable importance ranking according to $\triangle \mathrm{AIC}$, where 1 is the most important, is repre- 
et al. 2014a,b). In regard to the aforementioned exceptions, the daytime use of areas closer to water courses by adult bears in Greece suggests an attempt to cope with the high ambient temperatures of the Mediterranean landscape (de Gabriel Hernando et al. 2020). In addition, females were closer to grasslands during the night, while males were closer to this habitat feature during the day, which could be the result of efforts by females to avoid males (Steyaert et al. 2016) while profiting from their use as important feeding areas (Mealey 1980).

Brown bears in Greece showed consistent habitat selection patterns across all bear categories for specific habitat features: they selected for areas with rough terrain and close to water courses, while avoiding primary and unpaved roads. This behavior should be interpreted as an attempt to avoid human disturbance (Nellemann et al. 2007), which is common among bears (Naves et al. 2003, Zarzo-Arias et al. 2018). Selection towards naturalized crops was also generally consistent across adult bears, highlighting their importance as feeding areas and/or movement corridors with low or moderate human disturbance (Ambarl 2012). We believe that the increase in the availability of such areas following the rural abandonment in Greece in combination with the use of shrublands by adult males has favored the dispersal of individuals in the country (Karamanlidis et al. 2021) and has been one of the main drivers of the spatial expansion and recovery of the brown bear in Greece (Bonnet Lebrun et al. 2020).

Differences in habitat selection for specific habitat features across bear categories might be due to the ability of females and subadults to anticipate habitat selection by adult males (Steyaert et al. 2016) and, consequently, avoiding them. For example, forests, shrublands and grasslands, which combined are considered as optimal bear habitat (Nielsen et al. 2004), were avoided by females and subadults. Similarly, adult females keeping away from human settlements might be viewed as an attempt to avoid dominant males that use these areas in search of humanassociated food resources; this behavior of adult males could be the result of a progressive loss of fear in the context of rural abandonment and decreased human persecution (Martínez-Abraín et al. 2019).

Habitat selection by brown bears in Greece varied between stationary and moving behaviors, which is not uncommon for bears in Europe (e.g. Scandinavia; Moe et al. 2007). These variations provide insights into the ecological role of the various habitat features: higher selection for a specific habitat for stationary behaviors (e.g. areas with rough terrain or water courses) could be considered as an indication of this specific habitat serving as refuge habitat (Moe et al. 2007), while higher selection for moving behaviors (e.g. shrublands) might indicate suitability as a movement corridor (Dickie et al. 2020). However, some disturbed habitats, such as areas close to human settlements that were selected by male bears or secondary roads that were selected by females, could act as attractive sinks due to a poorly perceived risk of human disturbance (Naves et al. 2003, Penteriani et al. 2018).

The results of the study provide detailed information on the ecological role of various habitat types that we recommend should be used to develop guidelines for species conservation and allow for prioritizing management actions that will promote the conservation of bears in Greece. At the same time, this information may also contribute to promoting the recovery/persistence of other (endangered) species inhabiting anthropogenic landscapes.

The circannual and circadian habitat use patterns provide information on how to limit interactions between bears and humans in space and/or time: it is of utmost importance to restrict human activity in natural areas which act as refuge areas (e.g. forests in areas with rough terrain) during the day in $\mathrm{lHY}$ and EM. In addition, the habitat selection patterns indicate the importance of (1) reducing human activity in bear habitat and (2) protecting/improving the condition (i.e. quantity and/or quality) of specific natural habitat types in order to protect bears (Pop et al. 2018). With regard to reducing human activity in bear habitats, this may be most important for suitable habitat positively selected in spring and summer, as during this period, bears are closer to human features and appear to use smaller areas (Berland et al. 2008), and because this is a critical time for cub survival (Planella et al. 2019).

Our results indicate that within the context of the anthropogenic Mediterranean landscape of Greece, specific types of habitat are critical for the conservation of the species. These include shrublands, grasslands and naturalized crops because of their importance as potential feeding and/or corridor areas, while areas with rough terrain and water courses appear to be highly important as refuge areas. The latter habitat feature is particularly important, especially when considering that it is already heavily impacted in the country (Dimopoulos et al. 2006) and that the effects of climate change in Greece are expected to be high (Giannakopoulos et al. 2009). On the other hand, avoidance of certain types of habitat should also inform bear conservation. In this respect, 
roads appear to be particularly important; the importance of roadless areas for the conservation of wildlife is globally acknowledged (Ibisch et al. 2016, Penteriani et al. 2018, Morales-González et al. 2020). From a management perspective, particular attention will also need to be given to high-risk areas (i.e. areas with increased human activity that appear to be attractive to bears such as the surroundings of human settlements, secondary roads or intensive crops) in order to prevent them from functioning as ecological traps (Northrup et al. 2012, Penteriani et al. 2018, Morales-González et al. 2020). Finally, safeguarding natural areas of suitable habitat that can act as corridors of dispersal and gene flow will be important for successful recolonization (Nellemann et al. 2007), the establishment of metapopulations and the reconnection of fragmented population units (Karamanlidis et al. 2018).

Acknowledgements. We thank all members of the NGO ARCTUROS who helped in setting up the study and assisted in the field work. We thank J. Naves for a thorough review of our study. Financial support was provided by ARCTUROS, Egnatia S.A., Vodafone Greece and the Vodafone Group Foundation. All research activities, including animal trapping, were carried out following the guidelines of the research permits 98924/4791/17-9-2007 and 119628/1442 of the Hellenic Ministry of Environment, Energy and Climate Change.

\section{LITERATURE CITED}

Ambarlı H (2012) Spatio-temporal ecology, habitat use and population size of brown bears (Ursus arctos) in Yusufeli, Turkey. PhD, Middle East Technical University, Ankara

Apps CD, McLellan BN, Woods JG, Proctor MF (2004) Estimating grizzly bear distribution and abundance relative to habitat and human influence. J Wildl Manag 68: 138-152

*Bartón K (2019) MuMIn: Multi-model inference. R package version 1.43.6. https://CRAN.R-project.org/package=Mu MIn

Berland A, Nelson T, Stenhouse G, Graham K, Cranston J (2008) The impact of landscape disturbance on grizzly bear habitat use in the Foothills Model Forest, Alberta, Canada. For Ecol Manag 256:1875-1883

Bonnet Lebrun AS, Karamanlidis AA, de Gabriel Hernando M, Renner I, Gimenez O (2020) Identifying priority conservation areas for a recovering brown bear population in Greece using citizen science data. Anim Conserv 23: 83-93

Byrne ME, McCoy JC, Hinton JW, Chamberlain MJ, Collier BA (2014) Using dynamic Brownian bridge movement modelling to measure temporal patterns of habitat selection. J Anim Ecol 83:1234-1243

Calenge C (2006) The package 'adehabitat' for the R software: a tool for the analysis of space and habitat use by animals. Ecol Model 197:516-519

Calenge C, Dray S, Royer-Carenzi M (2009) The concept of animals' trajectories from a data analysis perspective. Ecol Inform 4:34-41
Chapron G, Kaczensky P, Linnell JDC, von Arx M and others (2014) Recovery of large carnivores in Europe's modern human-dominated landscapes. Science 346: 1517-1519

* Collier B (2013) moveud: dynamic Brownian bridge movement model individual time-step utilization distributions. R package version 101. https://ftp.cc.uoc.gr/mirrors/CRAN/

Dahle B, Swenson JE (2003) Seasonal range size in relation to reproductive strategies in brown bears Ursus arctos. J Anim Ecol 72:660-667

de Gabriel Hernando M, Karamanlidis AA, Grivas K, Krambokoukis L, Papakostas G, Beecham J (2020) Reducing movement in Mediterranean landscapes: a case study of brown bears in Greece. J Zool (Lond) 311:126-136

* Dickie M, McNay SR, Sutherland GD, Cody M, Avgar T (2020) Corridors or risk? Movement along, and use of, linear features varies predictably among large mammal predator and prey species. J Anim Ecol 89:623-634

Dimopoulos P, Bergmeier E, Fischer P (2006) Natura 2000 habitat types of Greece evaluated in the light of distribution, threat and responsibility. Biol Environ Proc R Ir Acad B 106:175-187

Dugatkin LA, Reeve HK (eds) (2000) Game theory and animal behavior. Oxford University Press, New York, NY

* Elfström M, Davey ML, Zedrosser A, Müller M and others (2014a) Do Scandinavian brown bears approach settlements to obtain high-quality food? Biol Conserv 178: 128-135

Elfström M, Zedrosser A, Støen OG, Swenson JE (2014b) Ultimate and proximate mechanisms underlying the occurrence of bears close to human settlements: review and management implications. Mammal Rev 44:5-18

Garshelis DL (2000) Delusions in habitat evaluation: measuring use, selection, and importance. In: Boitani L, Fuller TK (eds) Research techniques in animal ecology: controversies and consequences. Columbia University Press, New York, NY, p 111-164

*Giannakopoulos C, Le Sager P, Bindi M, Moriondo M, Kostopoulou E, Goodess CM (2009) Climatic changes and associated impacts in the Mediterranean resulting from a $2^{\circ} \mathrm{C}$ global warming. Global Planet Change 68: 209-224

Güthlin D, Knauer F, Kneib T, Küchenhoff $\mathrm{H}$ and others (2011) Estimating habitat suitability and potential population size for brown bears in the Eastern Alps. Biol Conserv 144:1733-1741

* Hampe A, Petit RJ (2005) Conserving biodiversity under climate change: the rear edge matters. Ecol Lett 8:461-467

Heiberger R, Holland B (2004) Statistical analysis and data display. Springer, Berlin

Hinton JW, van Manen FT, Chamberlain MJ (2015) Space use and habitat selection by resident and transient coyotes (Canis latrans). PLOS ONE 10:e0132203

* Hinton JW, Proctor C, Kelly MJ, van Manen FT, Vaughan MR, Chamberlain MJ (2016) Space use and habitat selection by resident and transient red wolves (Canis rufus). PLOS ONE 11:e0167603

* Ibisch PL, Hoffmann MT, Kreft S, Pe'er G and others (2016) A global map of roadless areas and their conservation status. Science 354:1423-1427

Johnson KG, Pelton MR (1980) Prebaiting and snaring techniques for black bears. Wildl Soc Bull 8:46-54

Karamanlidis AA, Sanopoulos A, Georgiadis L, Zedrosser A (2011) Structural and economic aspects of human-bear conflicts in Greece. Ursus 22:141-151 
Karamanlidis AA, de Gabriel Hernando M, Krambokoukis L, Gimenez O (2015) Evidence of a large carnivore population recovery: counting bears in Greece. J Nat Conserv 27:10-17

Karamanlidis AA, Skrbinšek T, de Gabriel Hernando M, Krambokoukis L and others (2018) History-driven population structure and assymetric gene flow in a recovering large carnivore at the rear-edge of its European range. Heredity 120:168-182

Karamanlidis AA, Kopatz A, de Gabriel Hernando M (2021) Dispersal patterns of a recovering brown bear (Ursus arctos) population in a human-dominated landscape. J Mammal:gyaa173, https://doi.org/10.1093/jmammal/ gyaa173

Kranstauber B, Kays R, LaPoint SD, Wikelski M, Safi K (2012) A dynamic Brownian bridge movement model to estimate utilization distributions for heterogeneous animal movement. J Anim Ecol 81:738-746

Kranstauber B, Smolla M, Scharf AK (2019) move: visualizing and analyzing animal track data. $\mathrm{R}$ package version 3.2.2. https://CRAN.R-project.org/package=move

Linnell JDC, Swenson JE, Andersen R, Barnes B (2000) How vulnerable are denning bears to disturbance? Wildl Soc Bull 28:400-413

Linnell J, Salvatori V, Boitani L (2008) Guidelines for population level management plans for large carnivores. https://ec.europa.eu/environment/nature/conservation/ species/carnivores/pdf/guidelines_for_population_level_ management.pdf

Manly BFJ, McDonald LL, Thomas DL (2002) Resource selection by animals: statistical design and analysis for field studies. Kluwer Academic, Boston, MA

Manning AD, Lindenmayer DB, Nix HA (2004) Continua and Umwelt: novel perspectives on viewing landscapes. Oikos 104:621-628

Martin J, Tolon V, Van Moorter B, Basille M, Calenge C (2009) On the use of telemetry in habitat selection studies. In: Martin J (ed) Habitat selection and movement by brown bears in multiple-use landscapes. $\mathrm{PhD}$ thesis, Université Claude Bernard, Lyon p 86-104. http:// bearproject.info/old/uploads/publications/thesisJM6.pdf

Martin J, Basille M, Van Moorter B, Kindberg J, Allainé D, Swenson JE (2010) Coping with human disturbance: spatial and temporal tactics of the brown bear (Ursus arctos). Can J Zool 88:875-883

Martínez-Abraín A, Jiménez J (2016) Anthropogenic areas as incidental substitutes for original habitat. Conserv Biol 30:593-598

Martínez-Abraín A, Jiménez J, Oro D (2019) Pax Romana: 'refuge abandonment' and spread of fearless behavior in a reconciling world. Anim Conserv 22:3-13

May R, Van Dijk J, Wabakken P, Swenson JE, Linnell JD, Zimmermann B (2008) Habitat differentiation within the large-carnivore community of Norway's multiple-use landscapes. J Appl Ecol 45:1382-1391

Mealey SP (1980) The natural food habits of grizzly bears in Yellowstone National Park, 1973-74. Bears Biol Manag 4:281-292

Mertzanis G, Kallimanis AS, Kanellopoulos N, Sgardelis SP, Tragos A, Aravidis I (2008) Brown bear (Ursus arctos L.) habitat use patterns in two regions of northern Pindos, Greece-management implications. J Nat Hist 42: 301-315

Mertzanis G, Giannakopoulos A, Pylidis C (2009) Ursus arctos (Linnaeus, 1758). In: Legakis A, Maragou P (eds) Red data book of the threatened animal species of Greece. Hellenic Zoological Society, Athens, p 387-389

Mertzanis G, Psaroudas S, Karamanlidis AA (2020) LIFE-IP 4 NATURA: Integrated actions for the conservation and management of Natura 2000 sites, species, habitats and ecosystems in Greece-Action Plan for the brown bear (Ursus arctos). Hellenic Ministry of Environment and Energy, Athens

* Moe TF, Kindberg J, Jansson I, Swenson JE (2007) Importance of diel behaviour when studying habitat selection: examples from female Scandinavian brown bears (Ursus arctos). Can J Zool 85:518-525

*Morales-González A, Ruiz-Villar H, Ordiz A, Penteriani V (2020) Large carnivores living alongside humans: brown bears in human-modified landscapes. Glob Ecol Conserv 22:e00937

Morrison ML, Margot BG, Mannan RW (2006) Wildlifehabitat relationships: concepts and applications. Island Press, Washington, DC

Naves J, Fernandez-Gil A, Delibes M (2001) Effects of recreation activities on a brown bear family group in Spain. Ursus 12:135-140

Naves J, Wiegand T, Revilla E, Delibes M (2003) Endangered species constrained by natural and human factors: the case of brown bears in northern Spain. Conserv Biol $17: 1276-1289$

* Nellemann C, Støen OG, Kindberg J, Swenson JE and others (2007) Terrain use by an expanding brown bear population in relation to age, recreational resorts and human settlements. Biol Conserv 138:157-165

Nielsen SE, Boyce MS, Stenhouse GB (2004) Grizzly bears and forestry I. Selection of clearcuts by grizzly bears in west-central Alberta, Canada. For Ecol Manag 199: 51-65

*Northrup JM, Stenhouse GB, Boyce MS (2012) Agricultural lands as ecological traps for grizzly bears. Anim Conserv 15:369-377

Ordiz A, Støen OG, Delibes M, Swenson JE (2011) Predators or prey? Spatio-temporal discrimination of humanderived risk by brown bears. Oecologia 166:59-67

Ordiz A, Kindberg J, Saebo S, Swenson JE, Stoen OG (2014) Brown bear circadian behavior reveals human environmental encroachment. Biol Conserv 173:1-9

*Paralikidis NP, Papageorgiou NK, Kontsiotis VJ, Tsiompanoudis AC (2010) The dietary habits of the brown bear (Ursus arctos) in western Greece. Mamm Biol 75:29-35

* Penteriani V, Delgado MDM, Krofel M, Jerina K and others (2018) Evolutionary and ecological traps for brown bears Ursus arctos in human-modified landscapes. Mammal Rev 48:180-193

Penteriani V, Karamanlidis AA, Ordiz A, Ciucci P and others (2020) Bears in human-modified landscapes: the case studies of the Cantabrian, Apennine, and Pindos Mountains. In: Penteriani V, Melleti M (eds) Bears of the world: ecology, conservation and management. Cambridge University Press, Cambridge, 260-272

Piédallu B, Quenette PY, Bombillon N, Gastineau A, Miquel C, Gimenez O (2019) Determinants and patterns of the endangered brown bear Ursus arctos habitat use in the French Pyrenees revealed by occupancy modeling. Oryx 53:334-343

* Planella A, Jiménez J, Palomero G, Ballesteros F, Blanco JC, López-Bao JV (2019) Integrating critical periods for bear cub survival into temporal regulations of human activities. Biol Conserv 236:489-495 
Pop IM, Iosif R, Miu IV, Rozylowicz L, Popescu VD (2018) Combining resource selection functions and home-range data to identify habitat conservation priorities for brown bears. Anim Conserv 21:352-362

Posillico M, Alberto MIB, Pagnin E, Lovari S, Russo L (2004) A habitat model for brown bear conservation and land use planning in the central Apennines. Biol Conserv 118: 141-150

R Core Team (2013) R: a language and environment for statistical computing. R Foundation for Statistical Computing, Vienna

Riley SJ, DeGloria SD, Elliot R (1999) A terrain ruggedness index that quantifies topographic heterogeneity. Intermount J Sci 5:23-27

Schofield G, Bishop CM, MacLean G, Brown P and others (2007) Novel GPS tracking of sea turtles as a tool for conservation management. J Exp Mar Biol Ecol 347:58-68

Sih A, Ferrari MCO, Harris DJ (2011) Evolution and behavioural responses to human-induced rapid environmental change. Evol Appl 4:367-387

Steyaert SMJG, Leclerc M, Pelletier F, Kindberg J, Brunberg S, Swenson JE, Zedrosser A (2016) Human shields

Editorial responsibility: Matt Hayward,

Callaghan, New South Wales, Australia

Reviewed by: 3 anonymous referees mediate sexual conflict in a top predator. Proc R Soc B 283:20160906

Swenson JE, Ambarli H, Arnemo JM, Baskin L and others (2020) Brown bear (Ursus arctos; Eurasia). In: Penteriani V, Melleti M (eds) Bears of the world: ecology, conservation and management. Cambridge University Press, Cambridge, 139-161

USGS (2006) Shuttle radar topography mission, 1 arc second scene 2.0, February 2000. Global Land Cover Facility, University of Maryland, College Park, MD

*Worton BJ (1989) Kernel methods for estimating the utilization distribution in home-range studies. Ecology 70 : 164-168

* Zarzo-Arias A, del Mar Delgado M, Ordiz A, García JD and others (2018) Brown bear behaviour in human-modified landscapes: the case of the endangered Cantabrian population, NW Spain. Glob Ecol Conserv 16:e00499

Ziółkowska E, Ostapowicz K, Radeloff VC, Kuemmerle $\mathrm{T}$ and others (2016) Assessing differences in connectivity based on habitat versus movement models for brown bears in the Carpathians. Landsc Ecol 31: 1863-1882

Submitted: October 19, 2020

Accepted: December 14, 2020

Proofs received from author(s): March 2, 2021 